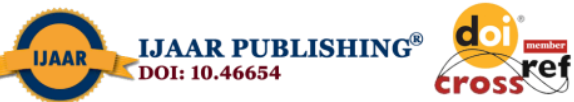

International Journal of Advanced Academic Research (Arts, Humanities and Education) | ISSN: 2488-9849

Vol. 6, Issue 11 (November, 2020) | www.ijaar.org

Journal DOI: 10.46654/ij.24889849

Article DOI: 10.46654/ij.24889849.a61125

\title{
ACHIEVING CURRICULUM INNOVATION IN POLYTECHNIC EDUCATION IN NIGERIA FOR CREATIVITY
}

\author{
Ikelegbe, Samuel \\ Department of office Technology and Management \\ Delta State Polytechnic, Ogwashi Uku \\ ikelegbesamuel@yahoo.com
}

\begin{abstract}
Innovative curriculum describes the creative initiatives in curriculum planning and implementation processes by learners, teachers and curriculum specialist. It is a curriculum which represents a world class curriculum; such a curriculum is defined by its principles, skills and values to be taught to students. The polytechnic education in Nigeria is geared towards providing middle-level manpower to man the various sectors of the Nigeria economy. Polytechnic education is regulated by the National Board for Technical Education (NBTE), whose aims among others are to supervise polytechnics and to provide standardized minimum guide curricula for the training of students. The curriculum which is currently in use in some of the programmes for ND and HND were handed over to the Polytechnics for implementation since 2004 and many of the curriculum used in various programmes have not been reviewed for the past 16 years. This situation cannot enhance innovation in the polytechnic education since change is known as the only permanent thing. To meet up with the required standard, a review of the polytechnic curriculum which will bring additional innovation is advocated so as to achieve a curriculum that represents a world class curriculum. The curriculum should be learner centered and competency based. To achieve the objectives of the polytechnic curriculum, the national aim, institution aim and the objectives in the classroom must complement each other. The teacher who is the agent in curriculum implementation process must work in tandem with the general objectives in order to impact meaningfully on the learners. It was concluded that curriculum holds an outstanding place when seeking to promote innovation in education. It was recommended that NBTE should be more proactive in order to refocus Polytechnic education to meet international standard and that management of Polytechnics should endeavor to provide the right manpower, instructional materials, laboratories, workshops and other infrastructural amenities that will aid learning among others.
\end{abstract}

Keywords: Curriculum, Innovation, Polytechnic Education, Creativity. 


\section{Introduction}

Education is regarded as the process of transmission, preservation and improvement of the culture of a people. It is a process through which human beings become morally good members of their society. Education helps individual to realize their potentials and thereby improving society. According to Ocho in Offorma (2016), apart from the inculcation of values, the other purposes of education include acquisition of knowledge, understanding and physical skills. A good and functional educational system targets buoyant economic, political, moral, spiritual and healthy development of a nation, Education is the basic force for the socio-economic and political transformation of society. In 2016, Offorma describe education as something more than schooling, she added that people are schooled to accept a society but that they are educated to create or recreate one. Education can therefore be explained as becoming critically aware of one's reality in a manner that ends with reflective action upon it. This enables an individual to understand his world well enough to deal with it effectively.

Polytechnic education in Nigeria is recognized as part of tertiary institutions whose aim is to provide middle-level manpower to man the various sectors of Nigeria economy (Ikelegbe and Odede, 2012). The polytechnic programmes are designed as two tier programme of studies, namely; the National Diploma (ND) and the Higher National Diploma (HND) with one year period of industrial experience which is a pre-requisite for entry into the Higher National Diploma programmes.

The National Board for Technical Education, otherwise known as NBTE, is a board of education which supervises, regulates and oversees educational programmes offered by technical institutions including Polytechnics and Monotechnics through an accreditation process. NBTE was established by an Act No 9 of July 1977, August 1985 and January 1993 with the aim of providing standardized minimum guide curricula for Technical and Vocational Education and Training (TVET) in Nigeria (NBTE 2015). The mission of NBTE is to promote the production of skilled technical and professional manpower for development and sustenance of the national economy. This is achieved through supervision of polytechnics and other allied institutions through professional assessors of the Board who visit institutions, to ensure that the national skills qualifications as embedded in the curriculum are achieved.

\section{Curriculum and Curriculum Structure of the Polytechnic}

The term curriculum according to Oteh and Akuma (2011) has not yet lent itself to any universally accepted definition as experts have not yet fully agreed on its exact meaning. Definitions have however changed with time and have to a large extent, reflected varying conceptions. Brubacher in Iboro and Nsidibe (2012) referred to curriculum as a ground which pupils and teachers cover in order to reach the goal of education. In order words, it can be regarded as a total experience with which the school deals with educating young people. That is, all the experiences both curricular and co-curricular which children pass through to become what is known as an educated person.

The common wealth of learning (2000) define curriculum as a composite whole including the learner, the teacher, teaching and learning, methodologies, anticipated and unanticipated experiences outcomes possible within a learning institution. Odesanya in Ikelegbe \& Odiachi (2017) described the curriculum as a group of planned experiences in proper sequences of topics designed to prepare individuals for efficient services in a specific 
vocation. From the definitions, it is pertinent to note that for a curriculum to be meaningful, it must take into cognizance, the learners and the environment. The curriculum can be seen as a process which aid in the development of educational experience and activities which will achieve for the pupils and all members of society some predetermined objectives.

The structures of the curriculum currently in use in the Polytechnic for all programmes consist of four semesters at the National Diploma and another four semesters at the Higher National Diploma Level. This includes classrooms contacts, laboratories, and workshops activities in the institutions. At the National Diploma Level, there is the 3-4 months Supervised Industrial Work Experience Scheme (SIWES) which takes place at the second semester of the first year (few departments are exempted) also there is the mandatory one year industrial work experience scheme after the National Diploma programme, preceding the Higher National Diploma programme. The curriculum presently use to achieve the aim of the Polytechnic education for both the ND and HND programmes are designed and handed over to the Polytechnics for implementation by NBTE. It should be pointed out that while the courses so design to be implemented for the programmes, cannot be deleted by those implementing for any reason, the various programme managers are allowed through the local content committee to add to the courses after Academic Board of the polytechnic(s) have approved such addition.

Some of the programmes in the Polytechnics curriculum were approved since 2004 for implementation and so many of the programmes have not been reviewed due to the rigidity of the curriculum planners. Ikelegbe and Odiachi (2017) have position that a situation where until NBTE comes with a revised curriculum, no institution within the purview of NBTE can delete any course that is not in tune with the present reality is not good for our system. The impact of this is that regardless of the times, students learning content is not made for their unique experience. The question is how long should the polytechnic curriculum take for another review to take place? Observation by Umoru (2019) showed that the curriculum for OTM programme in the polytechnics was last reviewed in 2004 and 15 years after, it has not been reviewed. He noted that, this is not good. How can a curriculum used in this millennial age be not reviewed for that long? Is it true that all courses presented by NBTE since 2004 are still relevant? Is it true that all the contents in the courses presented still meet up with the present technology office of today?

Iredia, Oboh and Umokoro (2018), while advocating for the need for review of Office Technology and Management curriculum, stated that such review should follow the principle of vocational curriculum such as:

1. Each curriculum should be explicitly organized to achieve the desired aims.

2. Each curriculum should be broad and have a balanced reflection of the whole range of stated aims and objectives.

3. It should ensure that it focuses primarily on those things that are most important and what is considered not essential is omitted.

4. Selection of learning experience should be based on the extent to which the knowledge and skill to be acquired will be usable in the various circumstances that the trainees are likely to experience in their future lives.

5. The curriculum should be achievable within the stipulated period of the programmes. Besides, the structure of course content should have a general view and coverage of professional or core courses. In particular, the professional or core courses which must be 
emphasized should consist of all important subjects which provide skills to enable the students on completion of the programmes to be able to perform all the skills in their specialized field of study as well as prepare him or her to be able to adjust easily to technological changes.

6. Finally, practical work in the training of skilled personnel must be adequately emphasized.

\section{Innovative Curriculum Design in the Polytechnic for Creativity}

Innovation is the injection of new idea(s) into a system to bring about improvement, it may propel by a shift in idea. The shift in idea could be due to rethinking new approach toward solving a perpetual challenge or an attempt to better an existing structure. To be innovating therefore means to be able to create something new (Binuomote in Ayo 2016). Oduma (2012) defined the term innovation as the process of both generation and applying creative ideas in some specific contents while creativity is reserved to apply mainly to the generation of novel ideas by individuals or groups. Amabile in Ayo (2016), in support of the above stated that innovation starts with creative ideas and creativity is the root upon which innovation stands. Creativity is a vital step within the preview of innovative process.

Curriculum holds an outstanding place when seeking to promote innovation in education as it reflects the vision for education, by indicating skills and values to be taught to students. Curriculum innovation therefore describes the creative initiatives in curriculum planning and implementation processes by learners, teachers and curriculum specialist (Mill 2011). Curriculum innovation can include new subjects, combination of old subjects or cross-cutting learning objectives. This is to ensure that the school curriculum meet with expectations.

Mandela in Peck (2018) stated that the school curriculum must prepare young people for an uncertain future because employers want people who can think intuitively, who are imaginative and innovative, who can communicate well, work in teams and are flexible, adaptable and self confident. The polytechnic curriculum can achieve innovative process if the handlers are proactive and move within the scope of the present technology and the entire world.

Innovative curriculum is that which represent a world class curriculum. A world class curriculum according to Peck (2018), is defined therefore by the principles rather than by a set content. Such a curriculum should be:

1. Rooted in values, have outcomes expressed as aims and be founded on firm principles.

2. Secure key competencies for learning and life.

3. Secure achievements in the world's major branches of learning.

4. Ensure learning takes place in meaningful context.

5. Rooted in its locality and context.

6. Meet the needs of its learning

7. Take national requirement and international expectations and put them in a local setting.

8. Make learning real, exciting and inspirational.

9. Develop the whole person-intellectual, aesthetic, physical, emotional, spiritual and social.

10. Excite imaginations and fire curiosity.

11. Raise aspirations and widen horizons.

12. Enable every learner to leave school with the confidence, ability and desire to make the world a better place. 


\section{The Context for Curriculum Innovation}

The intended curriculum according to Peck (2018) should be focused on the:

1. National expectations and the trend should be base upon value, aims and principles of the nation. It should be base upon clear shared values, which put learners at the heart of the curriculum and recognize their role as citizens of the world.

2. Education research: the global focus should be on a competency-based, learner-centre curriculum and values education.

3. Demographic, economic and social change which will ensure development of competencies for learning and life and a sense of hope in every learner.

4. The impact of technology which will excite the imagination, encourage curiosity and develop creativity.

5. Recognize employer and higher education needs. Which will help in understanding learning as it affects different disciplines and how they are inter-connected and relevant to life, global issues and world events, past present and future?

6. The local community, national and global contexts. This should be geared toward locating learning in the context of learner's life, and address contemporary issues as well as the big ideas that have shaped the world.

7. Parental expectations such as acquiring competencies, encourage independence of mind and action and the development of individual interest and talents.

8. School trends and inclusion of relevant areas of learning that will provide path ways for learning and the flexibility to respond to developing needs, interest and contexts.

9. Young people's own perspectives; that should provide exciting opportunities for the intellectual, physical, emotional, social, scientific, aesthetic and creative development of every learner.

\section{Curriculum Innovation Trends and Design Principles}

According to Mills in Oteh and Akuma (2011), innovation is often willed and planned for. It does not occur spontaneously or haphazardly. So if there is a deliberate, novel and specific change in the curriculum on the basis of the fact that it will be more efficacious or effective in the attainment of the objectives, we conclude that an innovation has taken place. Curriculum innovation in any school system could be in the goals and objectives of education, content, learning experiences, curriculum materials, and evaluation procedures. A worthwhile innovation ought to be purposeful, especially when it is to solve some problems. Some major reasons for curriculum innovation in institutions of learning according to Oteh and Akuna (2011), includes: pressure from social order, dynamic nature of knowledge; improved teaching and learning; research findings etc. Peck (2018) stated that innovative curriculum should consider what will produce better outcome for the future as presented below: 
Article DOI: 10.46654/ij.24889849.a61125

\begin{tabular}{|l|l|}
\hline Curriculum for the past 100 years & Curriculum fit for the future \\
\hline Teacher centred & Learner centred \\
\hline Knowledge based & Competency based \\
\hline Passive learning & Active learning \\
\hline Dependent & Independent \\
\hline Learning for exams & Learning for life \\
\hline Memorization & Higher order thinking \\
\hline Shallow learning & Deep learning \\
\hline Divers subjects & Connected learning \\
\hline 'Alien' knowledge & Relevant learning \\
\hline
\end{tabular}

Adapted from curriculum foundation, British Council.

\section{Curriculum Implementation}

The achievement of objectives of any level of education is largely dependents on effective implementation of its planned programme. Onyeachu in Ali and Ajibola (2015) observed that no matter how well a curriculum of any subject is planned, designed and documented, implementation is important. This is because the problem of most programmes arises at the implementation stage. According to Babalola (2004), it is at the implementation stage that many excellent curriculum plans and other education policies are marred without any trace. It is a very crucial stage where utmost care is required to achieve objectives.

Okebukola in Iboro and Nsidibe (2012) define curriculum implementation as the translation of the objectives of curriculum from paper to practice. They further notes that the process of curriculum implementation begins when the teacher is handed the curriculum and ends when learners have been exposed to the learning experiences prescribed in the document. Iboro and Nsidibe (2012) further stated that the intermediate steps in curriculum implementation include teaching through verbal and non-verbal exposition, practical work laboratories, workshops and in the field, student-student interactions, student-material interactions and then evaluation and feedback. To Garba (2004), curriculum implementation is putting the curriculum into work for the achievement of the goals for which the curriculum is designed.

Implementation of the curriculum according to Peck (2018) is possible if the implementation reflects the intended or official curriculum as defined by the frameworks and guidelines that specifies what students should be taught and learn, this depends on whether those to implement understood what is expected of them and this, equally depends on available instructional materials provided for effective teaching and learning as depicted below: 


\begin{tabular}{|c|c|c|}
\hline \multicolumn{3}{|c|}{ Achieving Implementation intent } \\
\hline \begin{tabular}{l|l} 
National \\
\end{tabular} & School & Classroom \\
\hline $\begin{array}{l}\text { To what extent has } \\
\text { government made the } \\
\text { objectives of the school } \\
\text { curriculum clear? }\end{array}$ & $\begin{array}{l}\text { To what extent has the } \\
\text { administrators made the } \\
\text { objectives of the } \\
\text { curriculum clear? What are } \\
\text { the learning facilities } \\
\text { available to achieve the } \\
\text { objectives? To what extent } \\
\text { do the objectives of the } \\
\text { school align with national } \\
\text { policy objective? }\end{array}$ & $\begin{array}{l}\text { What do teachers think their } \\
\text { objectives are in teaching } \\
\text { each subject? To what extent } \\
\text { do teacher objectives align } \\
\text { with the school objectives? }\end{array}$ \\
\hline $\begin{array}{l}\text { How effectively are the } \\
\text { objectives of the } \\
\text { curriculum translated into } \\
\text { policy viewer }\end{array}$ & $\begin{array}{l}\text { How effectively are the } \\
\text { objectives for the school } \\
\text { translated into policies and } \\
\text { processes? }\end{array}$ & $\begin{array}{l}\text { How likely is it that, the } \\
\text { teaching methods use will } \\
\text { deliver the subject } \\
\text { objectively? }\end{array}$ \\
\hline $\begin{array}{l}\text { What is the potential } \\
\text { impact of the policy } \\
\text { objectives on learners } \\
\text { nationally? }\end{array}$ & $\begin{array}{l}\text { What is the potential } \\
\text { impact of the schools } \\
\text { objectives on its learners? }\end{array}$ & $\begin{array}{l}\text { What is the potential impact } \\
\text { of the course/programme of } \\
\text { study on the learners? }\end{array}$ \\
\hline
\end{tabular}

From the table, implementation of any planned curriculum could be achieved if the national objectives are made clear and they are effectively translated into policies. Secondly the extent to which the school made the objectives clear and provide the facilities, which could help facilitators effectively translate the policies into processes that will impact on the learners, will be an added advantage.

The third is that the implementation stage of the curriculum takes place in the classroom, the teacher according to Ali and Ajibola (2015) is identified as the agent in curriculum implementation process, but the process could only be effective if the teachers objectives align with the school objectives, and the teaching methods used in delivery are not at variance with desired methods thereby impacting meaningfully on learners.

\section{CONCLUSION}

Curriculum holds an outstanding place when seeking to promote innovation in education as it reflects the vision for education by indicating knowledge, skills and values to be thought to students and should be a priority in schools curriculum. Curriculum innovation describes the creative initiative in curriculum planning and implementation processes by learners, teachers and curriculum planners. Curriculum innovation should be rooted in its locality and meet the need of learners that will impact on the national and international expectations. The trend should include relevant areas of learning that will provide pathways for learning and flexibility that will respond to new research and development. The context should provide exciting opportunities for intellectual, physical, emotional, social, scientific, aesthetic and creative development of every learner. 


\section{RECOMMENDATIONS}

Based on the forgoing, the following recommendations are proffered:

1. It is suggested that NBTE as a regulatory body should strengthen its regulatory mechanism and be more proactive in order to refocus Polytechnic education to meet international standard. This could be achieved through review of the polytechnic education curriculum as of when due. Courses that are not relevant could be deleted, while new areas which may be useful within the context of what is required at a particular time can be added.

2. Polytechnic management should endeavor to provide the right manpower, instructional materials, laboratories workshops and other infrastructural amenities that can aid learning in today's technological environment; there has been constant change, so it will be necessary for institutions to go with the times by adding to the amenities available to reflect what students will meet after graduation.

3. Curriculum planners have advocated that curriculum contents should be learner-centered, learning for life based on desired competency, this suggests that teachers/lecturers need to be developed or retrained to meet future standard. The curriculum can only succeed if the classroom teacher approaches it from the standpoint of knowledge and enthusiasm.

4. In developing the curriculum, all stakeholders in polytechnic education sector such as students, teachers, parents, the private sector, institution management and NBTE, which is the supervising body of the polytechnic sector should be involve in order to achieved a curriculum that could be referred to as world class.

5. Implementation stage of the curriculum should not be left at the hands of the teacher/lecturers alone. The supervising body should ensure that the national objectives is adhered to, also the institution should make the objectives clear and provide the pathway to arrive at the final objectives (competency desired) also the objectives of teachers should not be different from what both government and the school want to achieve so that the final impact on the students will be worthwhile. 


\section{REFERENCES}

Ayo, A.O. (2016). Innovative education as human capital development: catalyst for Nigeria's competitiveness in the global economy. Academy of Business Studies Journal 4(1), 181-188.

Ali, A.A. \& Ajibola, A.L. (2015). Issues and prospect of effective implementation of new secondary school curriculum in Nigeria. Journal of Education and Practice 6(34), 29-39.

Babalola, V.O. (2004). Resource materials in the implementation of curriculum in $21^{\text {st }}$ century in Noah A.O.K. in Shonibare D.O., Ojo.A.A and Olajuwon, T. (ed). Curriculum implementation and professional teaching in Nigeria. Lagos: Central Education Services.

Common Wealth of Learning (2000). Module 13: Curriculum theory, design and assessment. Pretoria. RSA: South African Development Community and Colleges. Garba, M. (2004). The critical role of education. Lagos: NERDC press.

Ikelegbe, S. \& Odede, J. O. (2012). Challenges in implementing the reformed office technology and management curriculum in polytechnics in Nigeria. Association of Business education of Nigeria Book of Readings. 2(1), 221-226.

Ikelegbe, S. \& Odiachi, B. (2017). Emerging issues in curriculum development in business education. Academy of Business Studies Journal. 5(2), 214-225.

Iredia, B.E., Oboh, G. A. \& Umokoro, S. (2018). The need for curriculum review for office technology and management. Association of Business Educators of Nigeria conference Proceedings. 5(1), 92-96

Iboro, U. \& Nsidibia, S. U. (2012). Curriculum development and challenges for Nigeria education system. Nigeria Journal of curriculum and Instruction. 20(1), 1-8.

Mills, G. (2011). Why curriculum innovation matters. National Foundation for Education. Retrieved 18/03/2020 from www.researchgate.net

NBTE (2015). Brief history of national board for technical education. Retrieved 8/04/ 2020 from http;/net.nbte.gov.ng

Offorma, G. O. (2016). The purpose of teacher education in Nigeria. Teacher Education in Nigeria Book of Reading (ed) by U.M.O. Ivowi, in honour of Prof. Mrs. Victoria Adaobi Obasi. Imo State University, Owerri, Imo State.

Oteh, J. E. \& Akuma, N. (2011). Curriculum development and innovation. Aba: Eagle and Joy Educational publishers.

Oduma, C. A. (2012). Principles and practice of entrepreneurship development. Abakaliki. Citizenship Advocate Publishers.

Peck, L. (2018). Innovative curriculum design. Partner school global network: Bristish Council. Retrieved 15/04/2020 from http://www.curruculumfoundation,org. 
International Journal of Advanced Academic Research (Arts, Humanities and Education) | ISSN: 2488-9849

Journal DOI: 10.46654/ij.24889849

Vol. 6, Issue 11 (November, 2020) | www.ijaar.org

Article DOI: 10.46654/ij.24889849.a61125

Umoru, T. A. (2019). Plotting pathways across transformational changes in business education. A desideratum for empowering learners to engage the world. Association of Business Educators of Nigeria, conference proceedings. 6(1)1-16. 